\title{
Some herbs reduce the hight of blood sugar, blood cholesterol in alloxan- diabetic rats.
}

\author{
Iman Abdulhadi M. AL-Blooni
}

Nutrition and food science, Home Economics Department, Jazan University

\section{ABSTRACT}

The present study was carried out to investigate the effect using 5\% and $10 \%$ of different dried mixture from (dill and goadid) and (chicory and rosemary) on serum glucose and lipid profile, kidney function of diabetic rats.

A total of 36 male rats $(120 \pm 5 \mathrm{gm}$ body weight) were used in this study. Rats were divided into two main groups, the first group (1) was used as control (-ve) group (6 rats) and fed on the basal diet only, the second group (2) (30 rats) was injected with $150 \mathrm{mg} / \mathrm{kg} \mathrm{B.W}$. alloxan to induce hyperglycemic in rats and then divided into (5) subgroup, one of these group was used as control (+ve) group received on basal diet only, the other four subgroups fed on basal diet containing 5\% or $10 \%$ on one of the different mixture plant as previously. The experimental feeding period was 28 days. The results revealed that.

All treatment of experimental diets with different levels showed significant reduction in serum glucose, triglycerides, low-density lipoprotein (LDL-c) and very low-density lipoprotein (VLDL-c) as compared to the positive control group. These results are of great importance because cardiovascular diseases (CVD) are statistically related to the high TC. Level in blood serum.

Addition of experimental mixture (dill and goadid) (5\% and10\%) to the diets resulted in improvement of body weight gain.

All treatment of experimental diets especially addition $10 \%$ mixture of (dill and goadid) increased serum concentration of high-density lipoprotein cholesterol (HDL-c).

All treatment of experimental diets decreased the concentration of serum uric acid, urea nitrogen and creatinin concentrations in diabetic rats.

Keywords: Herbs, blood sugar, blood cholesterol, rats

\section{INTRODUCTION}

Diabetes is a key factor in the predictive equations for CVD.It is therefore appropriate that dietary advice determined to be of use the prevention and treatment of CVD should be considered as part of the advice for the prevention and treatment of diabetes (Anderson et al., 1991). The prevalence of type-2 diabetes mellitus is high in many developing communities, including many Arabic communities (Miller et al., 2002).

Proper nutrition is essential for anyone living with the diabetes. Control of blood glucose levels is only one goal of a healthy eating plan for people with diabetes. A diet for those with diabetes should also help achieve and maintain a normal body weight as well as prevent heart and vascular disease, which are frequent complications of diabetes (Melzig and Funki, 2007).

Diabetes remedy that is gaining popularity today is herbal treatment, with a variety of plant- derived preparations being promoted as capable of controlling blood 
sugar levels, in fact, herbal treatment for diabetes is not know. Plants and plant extracts were used to combat the disease as early as 1550 B. c., with as many as 400 (prescribed) before the development earlier this century of effective medications to control diabetes (Linda et al., 2006).

Hyperlipidemia is an associated complication of diabetes mellitus (Miller et al., 2002). Chronic hyperglycaemia in diabetes leads to overproduction of free radicals and evidence is increasing that these contribute to the development of diabetic nephropathy (Sharma et al., 2006). In recent years; a substantial body of evidence has indicated that free radicals contribute to cardiovascular disease. Oxidative modification of LDL is hypothesized to play a key role during the development of atherosclerosis. The use of antioxidants from dietary sources, including herbs and spices, is a promising alternative to the use of antioxidant supplements. In general, herbs have high antioxidant concentrations that have the potential to inhibit the oxidation of LDL .Like fruits and vegetables, herbs contain many different classes of anti oxidants in varying amounts. It has been shown that the intake of herbs can contribute significantly to the total intake of plant antioxidant. (Linda et al., 2006).

Melzig and Funke, (2007) reported that antidibetics of plant origin are in common use. A proof of their effectiveness or their mode of action is often missing. Herbal alpha- amylase inhibitors are rarely described in the literature; nevertheless they have the ability to lower postprandial blood glucose level and should be used in the supplementary treatment of diabetes. Important constituents for the inhibitory activity against alpha-amylase are mainly polyphenolic compounds.

Therefore, the present work was conducted to study the effect of diets containing some different dried mixtures of plant herbs with different levels (5\% and $10 \%)$ of them on diabetic rats.

\section{MATERIALS AND METHODS}

-All food items have been bough (from local markets, Egypt.) fresh and prepared for experiment.

-Kits used to determine serum glucose; cholesterol, triglycerides, HDL-c, LDL-c, VLDL-c, Urea, uric acid, creatinin, were obtained from Egyptians American Company for laboratory service and supplied by Alkan Company. Thirty six male albino rats Spurge Dawley strain weighing and average $120 \pm \mathrm{gm}$ each were used in this study. The basal diet used in experiment was formulated according to (AOAC, 1995). After one week period, the rats were divided into two main groups, the first group (6 rats) fed on basal diet and were used as negative control group (-ve), the second group (30 rats) treated subcutaneous injection with alloxan $(150 \mathrm{mg} / \mathrm{kg}$ body weight) to induce hyperglycemia in the rats (Buko et al.,1996) and then divided into (5 subgroup) .

\section{Biochemical analysis of serum}

Glucose was determined in the serum according to the method described by (Tietz, 1976). Total cholesterol was determined in the serum according the method described by (Allain et al., 1974). Triglycerides were determined in serum according to the method described by (Trinder and Ann, 1969). Determination of serum HDLcholesterol was carried out according to the method of (Fredewaid, 1972 and Gordon and Amer, 1977). The determination of serum VLDL-cholesterol and LDL-c were carried out according to the method of (Lee and Nieman, 1996). Serum creatinin was determined according to the method described by (Henry, 1974). Serum uric acid was 
determined according to the method described by (Fossati., 1980) .Serum urea nitrogen was determined according to the method described by (Patton and Cruch,1977).

The obtained data were statistically analyzed by using computer. The results were tested for significance using one way analysis of variance (ANOVA) test according to (Armitage Berry, 1987).

\section{RESULTS AND DISCUSSION}

Effect of different mixture of plant herbs on serum glucose levels of diabetic rats:

Data of Table (1) show the serum glucose level of diabetic rats fed on different mixture investigated plants. All studied samples proved to be medicinal mixture plants as they significantly decreased the serum glucose level as compared to positive (+ve) control group. The best result of serum glucose recorded for diabetic group fed on basal diet containing $10 \%$ and $5 \%$ (dell and goadaid) because this treatment showed non-significant changes in serum glucose level as compared to negative control groups.

Table 1: Effect of different mixture of plant herbs on serum glucose levels of diabetic rats:

\begin{tabular}{|l|l|}
\hline Groups & Glucose(mg/dl) $\mathrm{M} \pm \mathrm{SD}$ \\
\hline Group (Control-ve) (A) & $96 \pm 0.5 \mathrm{c}$ \\
\hline Group (Control +ve) (B) & $198 \pm 0.2 \mathrm{a}$ \\
\hline Dill and Goadaid 5\% & $95 \pm 2 \mathrm{c}$ \\
\hline Dill and Goadaid 10\% & $93 \pm 0.55 \mathrm{c}$ \\
\hline Chicory and Rosemary 5\% & $127 \pm 20 \mathrm{~b}$ \\
\hline Chicory and Rosemary 10\% & $119.5 \pm 2.5 \mathrm{bc}$ \\
\hline
\end{tabular}

All results are expressed as mean $\pm S D$

Values in each column which have different letters are significantly different $(P<0.05)$

Delzenne et al., (2005) reported that dietary inulin-type fructans extracted from chicory root decreased glycaemia, increased pancreatic and serum insulin content in diabetic rats. The hypothesis that dietary inulin-type fructans could play a role in the management of obesity and diabetes their capacity to promote secretion of endogenous gastrointestinal peptides involved in appetite regulation.

Suzuki et al., (2002) suggested that intake of vegetables and fruits rich in carotenoids might be protective factor against hyperglycemia. Flavonoids are functional constituents of many fruits and vegetables. Some flavonoids have antidibetics properties because they improve altered glucose and oxidative metabolisms of diabetic states.

Platel and srinivasan, (1997) reported that vegetables are among numerous plant adjuncts tried for the treatment of diabetes mellitus, green leafy have shown the beneficial hypoglycemic influence in both experimental animals and humans.

Honda et al., (2006) reported that ingestion of turmeric oleoresin and essential oil inhibited the development of increased blood glucose and abdominal fat mass in obese diabetic mice. Curcumin, the principal active component of turmeric, is reported to exert a number of therapeutic actions, including a hypoglycemic/ antidibetics action. Best et al., (2007) reported that the stimulation of beta-cell function by curcumin could contribute to the hypoglycemic actions of this compound, and these findings identify a novel potential therapeutic target for the treatment of type 2 diabetes mellitus. 


\section{Effect of different mixture of plant herbs on lipid profile of diabetic rats:}

The effect of different tested mixture of plant herbs and spices on total cholesterol (TC), triglycerides (TG), high-density lipoprotein cholesterol (HDL-c), low-density lipoprotein (LDL-c) and very low density lipoprotein (VLDL-c) in diabetic rats, showed in Table (2).

Table 2: Effect of different mixture of plant herbs on lipid profile of diabetic rats.

\begin{tabular}{|c|c|c|c|c|c|}
\hline Groups & $\begin{array}{c}\text { Cholesterol(mg/dl) } \\
\mathrm{M} \pm \mathrm{SD}\end{array}$ & $\begin{array}{c}\text { Triglyceride(mg/dl) } \\
\mathrm{M} \pm \mathrm{SD}\end{array}$ & $\begin{array}{c}\text { HDL-c (mg/dl) } \\
\mathrm{M} \pm \mathrm{SD}\end{array}$ & $\begin{array}{c}\text { LDL-c } \\
(\mathrm{mg} / \mathrm{dl}) \\
\mathrm{M} \pm \mathrm{SD}\end{array}$ & $\begin{array}{c}\text { LDL-c } \\
(\mathrm{mg} / \mathrm{dl}) \\
\mathrm{M} \pm \mathrm{SD}\end{array}$ \\
\hline Group (Control-ve) (A) & $71.5 \pm 0.5 \mathrm{~b}$ & $32.5 \pm 2.5 \mathrm{~d}$ & $44 \pm 1 \mathrm{a}$ & $21 \pm 0.13 \mathrm{~h}$ & $6.5 \pm 0.5 \mathrm{~d}$ \\
\hline Group (Control +ve) (B) & $111 \pm 1 \mathrm{a}$ & $86.48 \pm 0.50 \mathrm{a}$ & $24 \pm 0.5 \mathrm{c}$ & $69.7 \pm 0.2 \mathrm{a}$ & $17.3 \pm 0.1 \mathrm{a}$ \\
\hline Dill and Goadaid 5\% & $85.5 \pm 1.05 \mathrm{~b}$ & $48.5 \pm 1.5 \mathrm{bcd}$ & $39.5 \pm 0.5 \mathrm{ab}$ & $36.3 \pm 0.2 \mathrm{~cd}$ & $9.7 \pm 0.3 \mathrm{bc}$ \\
\hline Dill and Goadaid 10\% & $74 \pm 5 \mathrm{~b}$ & $39.5 \pm 1.5 \mathrm{~cd}$ & $44 \pm 2 \mathrm{a}$ & $22.1 \pm 0.4 \mathrm{~h}$ & $7.9 \pm 0.3 \mathrm{~cd}$ \\
\hline Chicory and Rosemary 5\% & $88.5 \pm 15.5 \mathrm{~b}$ & $56 \pm 10 \mathrm{~b}$ & $37 \pm 2 \mathrm{~b}$ & $40.3 \pm 0.2 \mathrm{~b}$ & $11.2 \pm 2 \mathrm{~b}$ \\
\hline Chicory and Rosemary 10\% & $79.2 \pm 0.2 \mathrm{~b}$ & $43.5 \pm 2.5 \mathrm{bcd}$ & $42 \pm 2 \mathrm{ab}$ & $28.5 \pm 0.5 \mathrm{f}$ & $8.7 \pm 0.5 \mathrm{bcd}$ \\
\hline
\end{tabular}

All results are expressed as mean \pm SD

Values in each column which have different letters are significantly different $(\mathrm{P}<0.05)$

It could be noticed that the control (+ve) group has shown a significant increase $\mathrm{P}<0.05$ in the mean values of TC, TG, LDL-c and VLDL-c as compared with those of the control (-ve) group. Concerning the mean value of serum HDL-c, the control (+ve) group exhibited a markedly significant decrease as compared to the negative control group. Tested groups in the present study showed a significantly lower value in the serum of total cholesterol, TG, LDL-c and VLDL-c as compared to positive control group. On the other hand all treated groups with different levels of experimental diet induced a higher mean value of HDL-c as compared to the positive control group.

The obtained data revealed that, the highest improvement of lipid fraction recorded for the group of rats treated with $10 \%$ mixture of (dill and goadaid). In this respect Linda et al., (2006) reported that the antioxidant properties of herbs are of particular interest in view of the impact of oxidative modification of low-density lipoprotein cholesterol in the development of atherosclerosis. Herbs and spices have an important role in dietary flavonoids intake. Chamomile, onions, rosemary, sage and thyme have high flavonoids contents, but there is little evidence apart from epidemiological studies to support a direct cardiovascular health benefit from these herbs and spices.

Gehan, (2006) reported that basal diets containing goadaid reduced the levels of bad cholesterol (LDL-c) concentration, VLDL-c, TC and TG. She observed also good cholesterol (HDL-c) level was raised in diet with goadaid.

Exposure to high fruit and vegetable diet increases antioxidant concentrations in blood and body tissues and potentially protects against oxidative damage to cells and tissues Olmedilla et al., (2001).

\section{Effect of different mixture of plant herbs on kidney function of diabetic rats:}

The effects of different mixture plant herbs and spices on serum uric acid, urea nitrogen and creatinin $(\mathrm{mg} / \mathrm{dl})$ of diabetic rats are presented in Table (3). The mean values of urea nitrogen, uric acid and creatinin $(\mathrm{mg} / \mathrm{dl})$ for the positive control group showed significant increase $(\mathrm{P}<0.05)$, as compared to the negative control group (51 $\pm 1.73,2.33 \pm 0.15$ and $1.59 \pm 0.01$ vs. $36.5 \pm 0.5,1.6 \pm 0.4$ and $0.63 \pm 0.62)$ respectively.

Kidney function (urea nitrogen, uric acid and creatinin) for all treated groups with a different levels recorded significant decrease, $(\mathrm{P}<0.05)$, as compared to $(+\mathrm{ve})$ group. While non significant changes in uric acid and creatinin as compared to (-ve) group. 
The present study revealed that all tested diet used different mixture plant herbs may beneficial for patients infected with renal disorders because all of treatment showed a significant decrease in serum urea nitrogen, uric acid and creatinin when compared with the positive control group, on the other hand these concentration showed non significant changes when compared with the negative control group.

Table 3: Effect of different mixture of plant herbs on kidney function of diabetic rats

\begin{tabular}{|l|c|c|c|}
\hline \multicolumn{1}{|c|}{ Groups } & $\begin{array}{c}\text { Urea nitrogen } \\
(\mathrm{mg} / \mathrm{dl}) \mathrm{M} \pm \mathrm{SD}\end{array}$ & Uric acid $(\mathrm{mg} / \mathrm{dl}) \mathrm{M} \pm \mathrm{SD}$ & $\begin{array}{c}\text { Creatinin }(\mathrm{mg} / \mathrm{dl}) \\
\mathrm{M} \pm \mathrm{SD}\end{array}$ \\
\hline Group (Control-ve) (A) & $36.5 \pm 0.5 \mathrm{f}$ & $1.6 \pm 0.4 \mathrm{~b}$ & $0.63 \pm 0.62 \mathrm{~cd}$ \\
\hline Group (Control +ve) (B) & $51 \pm 1.73 \mathrm{a}$ & $2.33 \pm 0.15 \mathrm{a}$ & $1.59 \pm 0.01 \mathrm{a}$ \\
\hline Dill and Goadaid 5\% & $41.8 \pm 0.2 \mathrm{~d}$ & $1.7 \pm 0.05 \mathrm{~b}$ & $0.7 \pm 0.02 \mathrm{~b}$ \\
\hline Dill and Goadaid 10\% & $39.2 \pm 0.8 \mathrm{e}$ & $1.6 \pm 0.02 \mathrm{~b}$ & $0.64 \pm 0.02 \mathrm{~cd}$ \\
\hline Chicory and Rosemary 5\% & $43.7 \pm 0.3 \mathrm{c}$ & $1.7 \pm 0.27 \mathrm{~b}$ & $0.66 \pm 0.005 \mathrm{bcd}$ \\
\hline Chicory and Rosemary 10\% & $36.9 \pm 0.1 \mathrm{f}$ & $1.5 \pm 0.35 \mathrm{~b}$ & $0.65 \pm 0.01 \mathrm{bcd}$ \\
\hline
\end{tabular}

All results are expressed as mean \pm SD

Values in each column which have different letters are significantly different $(\mathrm{P}<0.05)$

At present, recommendations are warranted to support the consumption of food rich in bioactive components, such as herbs. With time, we can expect to see a greater body of scientific evidence supporting the benefits of herbs in the overall maintenance of health and protection from disease (Tapsell et al., 2006).

\section{REFERENCES}

Allain, C.; Poon, L. and Chan, C. (1974). Enzymatic determination of total serum cholesterol.Clin.Chem; 20:470-475.

Anderson, K. M.; Wilson, P. W.; Odell, P. M. and Kannel, W. B. (1991). An updated coronary risk profile: a statement for health professionals. Circulation, 83:356-62.

AOAC, (1995). Official methods of Analysis of the Association of Official Analytical Chemists, $15^{\text {th }}$ ed., Washington, D. C.

Armitage, P. and Berry, G. (1987). Statistical method in medical research Blackwell, oxford, UK, PP. 93-213.

Best, L.; Elliott, A. C. and Brown, P.D. (2007). Curcumin induces electrical activity in rat pancreatic beta-cells by activating the volume -regulated anion channel. Biochem Pharmacol, 73(11):1768-75.

Buko, V.; Luklvskaya, O.; Nkitin, V.; Tarasov, Y.; Zavodink, L.; Borodassky,A.; Cioren,T.; Shetein, B.; Tanz, B. and Mudermann, K. J. (1996). Hepatic and pancreatic effects of polyenoyl phatidyl choline in rats with alloxan induce diabetes. Cell Biochem; Furnet, 14(2):137.

Delzenne, N. M.; Cani, P. D.; Daubioul, C. and Neyrinck, A. M. (2005). Impact of inulin an oligofructose on gastrointestinal peptides. Br. J. Nutre. 93 suppl. 1:S157-61.

Fredewaid, W. T. (1972). Determination of HDL, Clin.Chem., 18-499.

Fossati, P.; Prencipe, L. and Berti, G. (1980). Enzymatic colorimetric method of determination of uric acid in serum. Clin. Chem., 26(2):227-273.

Gordon, T. and Amer, M. (1977). Determination of HDL J. of Med., 62:707.

Henry, R. J. (1974). Clinical Chemist.Principles and Techniqus, $2^{\text {nd }}$ Edition, Hagerstown (MD), Harcer, Row. pp.882.

Honda, S.; Aoki, F.; Tanaka, H.; Kishida, H.; Nishiyama, T.; Okada, S.; Matsumoto, I.; Abe, K. and Mae, T. (2006). Effects of ingested turmeric oleoresin on glucose and lipid metabolisms in obese diabetic mice :a DNA microarray study. J. Agric. Food Chem. 54(24):9055-62.

Lee, R. and Nieman, D. (1996). Nutritional assessment. $2^{\text {nd }}$ ed. Mosby, Missouri, USA. 
Linda, C.; Hemphill, L.; Lynne, C.; David, R.; Michael, F.; Craig, S.; Steven, R.; Jennifer, B.; Peter, M.; Peter, G.; Virginia, A. and Karen, E. (2006). Health benefits of herbs and spices: The past, the present, the future. M. J. A. 185:S1-S24.

Melzig, M. F. and Funki, I. (2007). Inhibitors of alpha-amylase from plants- a possibility to treat diabetes mellitus type 2 by phytotherapy? Wien Med. Wochenschr; 157 (13-14): $320-4$.

Miller, C. J.; Dunn, E. V. and Hashim, I. B. (2002). Glycemic index of 3 varieties of dates. Saudi. Med. J. 23(5):536-8.

Olmedilla, B.; Granado, F.; Southon, S.; Wright, A. J.; Blanco, I.; Gil-Martinez, E.; Berg, H.; Corridan, B.; Roussel, A. M.; Chopra, M. and Thurnham, D. I. (2001). Serum concentrations of carotenoids and vitamins $\mathrm{A}, \mathrm{E}$ and $\mathrm{C}$ in control subjects from five European countries. Br. J. Nutr. 85(2):227-38.

Patton, C.H. and Crouch, S.R. (1977). Enzymatic colorimetric method to determine urea in serum.Anal.Chem, 49:464-469.

Platel, K. and Srinivasan, K. (1997). Plant foods in the management of diabetes mellitus: vegetables as potential hypoglycaemic agents-Nahrung. 41(2):68-74.

Sharma, S.; Kulkarni, S. K. and Chopra, K. (2006). Curcumin, the active principle of turmeric (curcuma longa), ameliorates diabetic nephropathy in rats.Clin. Exp. Pharmacol Physiol. 33(10):940-5.

Suzuki, K.; Ito, Y.; Nakamura, S.; Ochiai, J. and Aoki, K. (2002). Relationship betweenserum carotenoids and hyperglycemia: a population-based cross-sectional study. J. Epidemiol. 12(5):357-66.

Tapsell, L. C.; Hemphill, I.; Cobiac, L.; Path, C. S.; Sullivan, D. R.; Fenech, M.; Roodenrys, S.; Keogh, J. B.; Clifton, P. M.; Williams, P. G.; Fazio, V. A. and Inge, K. E. (2006). Health benefits of herbs and spices. Med. J. Aust. 185:4-24.

Tietz, N. W. (1976). Fundamentals of clinical chemistry. Philadelphia, W. B. Saunders, P.243.

Trinder, P. and Ann, S. (1969). Enzymatic colorimetric test with lipid clearing factor to determine triglyceride. Clin. Biochem., 6:24-27

\section{ARABIC SUMMARY}

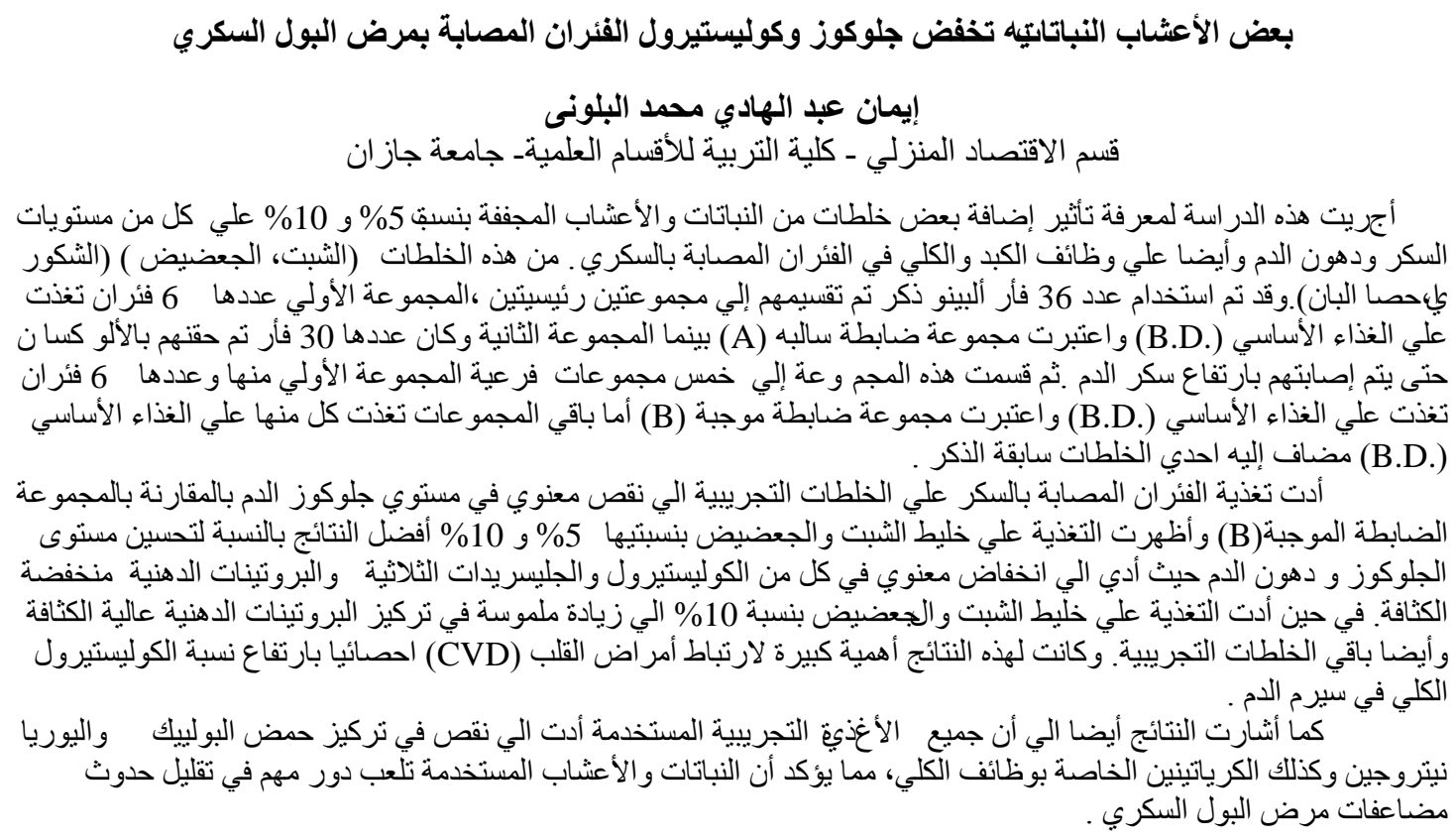

